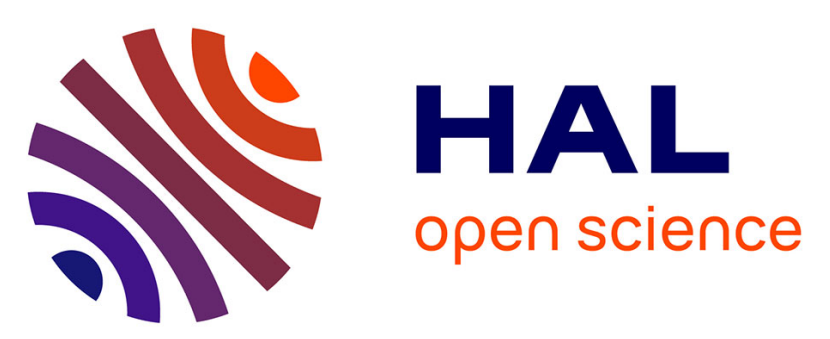

\title{
Effects of oxidative stress on protein thiols and disulphides in revealed by proteomics: actin and protein disulphide isomerase are redox targets
}

\author{
B. Mcdonagh, D. Sheehan
}

\section{- To cite this version:}

B. Mcdonagh, D. Sheehan. Effects of oxidative stress on protein thiols and disulphides in revealed by proteomics: actin and protein disulphide isomerase are redox targets. Marine Environmental Research, 2008, 66 (1), pp.193. 10.1016/j.marenvres.2008.02.069 . hal-00501961

\section{HAL Id: hal-00501961 \\ https://hal.science/hal-00501961}

Submitted on 13 Jul 2010

HAL is a multi-disciplinary open access archive for the deposit and dissemination of scientific research documents, whether they are published or not. The documents may come from teaching and research institutions in France or abroad, or from public or private research centers.
L'archive ouverte pluridisciplinaire HAL, est destinée au dépôt et à la diffusion de documents scientifiques de niveau recherche, publiés ou non, émanant des établissements d'enseignement et de recherche français ou étrangers, des laboratoires publics ou privés. 


\section{Accepted Manuscript}

Effects of oxidative stress on protein thiols and disulphides in Mytilus edulis revealed by proteomics: actin and protein disulphide isomerase are redox targets

B. McDonagh, D. Sheehan

PII:

S0141-1136(08)00085-8

DOI:

10.1016/j.marenvres.2008.02.069

Reference:

MERE 3231

To appear in:

Marine Environmental Research

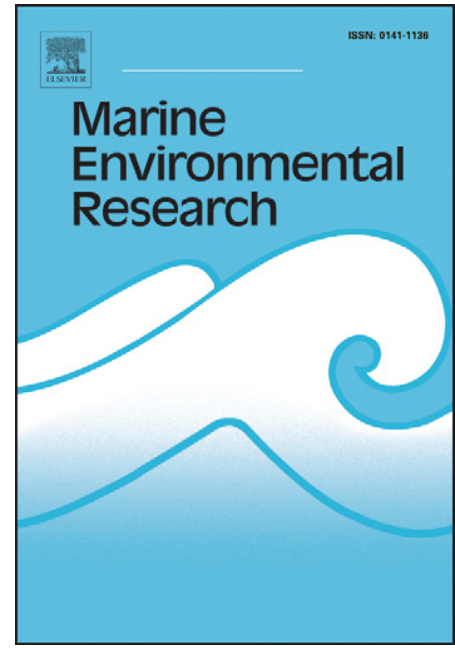

Please cite this article as: McDonagh, B., Sheehan, D., Effects of oxidative stress on protein thiols and disulphides in Mytilus edulis revealed by proteomics: actin and protein disulphide isomerase are redox targets, Marine Environmental Research (2008), doi: 10.1016/j.marenvres.2008.02.069

This is a PDF file of an unedited manuscript that has been accepted for publication. As a service to our customers we are providing this early version of the manuscript. The manuscript will undergo copyediting, typesetting, and review of the resulting proof before it is published in its final form. Please note that during the production process errors may be discovered which could affect the content, and all legal disclaimers that apply to the journal pertain. 


\title{
Effects of oxidative stress on protein thiols and disulphides in
}

\section{Mytilus edulis revealed by proteomics: actin and protein \\ disulphide isomerase are redox targets}

\author{
B. McDonagh, D. Sheehan * \\ Proteomics Research Group, Department of Biochemistry, Environmental Research Institute, University \\ College Cork, Cork, Ireland
}

\begin{abstract}
Many proteins contain cysteines which are sensitive to oxidation. This is sometimes reversible through interaction with glutathione, glutaredoxin or thioredoxin systems making these proteins potential sensors of oxidative stress. In this study we analysed whether there was an increase in mixed disulphide bond (-S-S-) formation in the blue mussel Mytilus edulis in response to menadione. This was achieved by initially blocking reduced thiols with $\mathrm{N}$ ethylmaleimide, -S-S- were then reduced with dithiothreitol (DTT) and labelled with 5iodoacetamidofluorescein (5-IAF). Free -SHs were also labelled directly with 5-IAF. Separations were performed on 1D or 2D SDS PAGE and images analysed. There was an increase in -S-S- in response to menadione and detection of changes in oxidised proteins was easier than that of changes in the amount of reduced proteins. Protein disulphide isomerase
\end{abstract}


(PDI) was labelled both as -SH and -S-S-, underlining its involvement in the redox status of the animal. A glutathione transferase (GST P1-1) forms an inter-chain disulphide bridge in response to menadione.

Keywords: Protein thiols; Oxidation; Oxidative stress; Proteomics; Mytilus edulis; Menadione

* Corresponding author. Tel + 35321 4904207; fax: +353 214274034.

E-mail address: d.sheehan@ucc.ie (D. Sheehan)

The "oxygen paradox" is that molecular oxygen is essential to aerobic life while, simultaneously, oxygen can form toxic reactive oxygen species (ROS) (Halliwell and Gutteridge, 2007). Antioxidant defences protect biological systems against ROS. If these defences are compromised, or if the levels of ROS exceed them, a state of oxidative stress (OS) ensues (Halliwell and Gutteridge, 2007). Many environmental pollutants such as organochlorines and metals promote OS. $\sim 70 \%$ of ROS are absorbed ultimately by proteins leading to structural changes including carbonylation, chain cleavage and glutathionylation (Davies, 2005). Thus, oxidative stress can significantly complicate the proteome, leading to structural variants of some proteins. Sulphur is notoriously susceptible to oxidation and both methionine and cysteine are oxidised in OS. It has been suggested that methionine primarily acts as an OS “buffer” in proteins. Cysteine contributes to protein structure by formation of disulphide bridges in the endoplasmic reticulum in a reaction catalysed by protein disulphide isomerise (PDI). We are interested in probing effects of OS on cysteines in proteins of the blue mussel, Mytilus edulis, a popular sentinel species. 
M. edulis, ( 4-7 cm length) were sampled from a site (51 49’ N 8 18’ W ) in Cork Harbour, Ireland (McDonagh and Sheehan, 2006). Three groups ( $n=5)$ of animals were held in tanks (1 week, 12 h light/dark cycle, at 34-36 \%o salinity and $17{ }^{\circ} \mathrm{C}$ temperature) with feeding and water changing (48h intervals; Phytoplex ${ }^{\mathrm{TM}}$ phytoplankton feed, Kent Marine Inc., Acworth, GA, USA). They were then exposed ( $24 \mathrm{~h})$ to $1 \mathrm{mM}$ menadione. Three control groups $(\mathrm{n}=5)$ were treated identically but not exposed to menadione. Gills were dissected, pooled (five animals), frozen (liquid nitrogen) and stored at $-70^{\circ} \mathrm{C}$. Tissues were homogenized $(10 \mathrm{mM}$ Tris/HCl, pH 7.2, 500mM sucrose, 1mM EDTA, 1mM PMSF), centrifuged at 20,000g (1h, $\left.4^{\circ} \mathrm{C}\right)$ and stored $\left(-70^{\circ} \mathrm{C}\right)$. Protein was determined with bovine serum albumin as a standard (Bradford, 1976).

Diagonal electrophoresis was used to probe effects of menadione exposure on interand intramolecular disulphide bridges (McDonagh et al., 2006). This revealed that the bulk of the protein stain was concentrated along the diagonal. However, when proteins were transferred to nitrocellulose membranes and probed for carbonylation, proportionately greater staining was detected off the diagonal in the sector corresponding to inter-chain disulphide bridges. $\sim 30 \%$ of the total carbonylation staining was concentrated in two clusters which respectively immunoblotted with antibodies either to actin or PDI, both of which form disulphide bridges with other proteins. To explore this further, protein thiols were labelled with iodoacetamide-fluorescein (IAF) and could be detected with anti-fluorescein (Baty et al., 2002). Some spots visible in the control were absent in the menadione-exposed immunoblot (Fig. 1). These we interpret as being due to -SH oxidation in key proteins. One form of cysteine oxidation involves formation of disulphide bridges. This could be detected by first treating the protein extract with $N$-ethyl maleimide (NEM), followed by reduction with dithiothreitol and reaction with IAF (Baty et al., 2002). Now, IAF only reacts with newlyrevealed -SH groups previously involved in disulphides. Menadione-exposed protein extracts 


\section{ACCEPTED MANUSCRIPT}

clearly contain more of these than control (Fig. 1). Spots were selected for in-gel tryptic digestion and identified by LC-tandem MS (Proteomics Facility, University of Aberdeen, Scotland). This identified the following proteins (accession no.s) with oxidized -SH groups: hsp gp96 (NP_999808); PDI (ABF48564); calreticulin (AAL40720); heavy metal binding protein (CAE81917); protease serine 1 (NP_444473). In addition, the following ten proteins with OS-induced-S-S- were also identified: alpha 2 tubulin (XP_001178141); PDI (ABF48564); beta-tubulin (BAA22381); gelsolin (CAC87029); enolase (AAF72641); GDP dissociation inhibitor (CAA64439); glutathione transferase Pi (GST P1-1, AAM91994); RNA binding protein (AAC41383); transferrin (AAN17090). PDI was common to both panels, confirming its importance in redox stress. The finding of menadione-induced disulphides in M. edulis GST Pi is particularly noteworthy. The mouse orthologue (mGSTP1-1) contains only one cysteine (Cys-47) which forms $-\mathrm{S}$-S- with low $\mathrm{M}_{\mathrm{r}}$ thiols in response to oxidative stress (Sluis-Cremer and Dirr, 1995). This is thought to be protective against OS. In M. edulis GST Pi, there are two cysteines (Cys-49 and Cys-51) flanking Pro-50 (Yang et al., 2004) which may carry out a similar function. Homology modelling with Geno3D enabled construction of a structural model using the mouse orthologue (mGSTP1-1) as a template (Sheehan and O’Donovan, 2006). Comparison of the model and template confirmed that Cys51 occupies the same location as Cys-47 of mGSTP1-1 and that Pro-50 is cis (Fig. 2). In menadione-treated mice, Cys-47 has previously been reported as forming -S-S- and the pKa of-SH is $\sim 4$ compared to the normal value in the region of 10 . Immunoblotting with antibodies to rGSTP1-1 showed that the $M$. edulis orthologue forms disulphide bridges with other, as yet unidentified proteins (Fig. 2C). This suggests an evolutionarily conserved formation of -S-S- in response to OS in Pi class GSTs.

Probing effects of pro-oxidants and environmental pollutants on protein thiol status

may offer a generally applicable route to detecting key proteins targeted by OS, some of 


\section{ACCEPTED MANUSCRIPT}

which may prove to be useful biomarkers and offer insight into biochemical processes in response to toxicity.

\section{Acknowledgements}

Our research is funded by IRCSET and PRLTI of the Higher Education Authority.

\section{References}

Baty, J.W., Hampton, M.B., and Winterbourn, C.C. (2002). Proteomics, 2, 1261-1266.

Bradford, M.M. (1976). Analytical Biochemistry, 72, 248-254.

Davies, M. J. (2005). Biochimica Biophysica Acta, 1703, 93-109.

Halliwell, B, and Gutteridge, J. (Ed.s), 2007. Free Radicals in Biology and Medicine (Fourth Edition) Oxford University Press.

McDonagh, B., and Sheehan, D. (2006). Aquatic Toxicology, 79, 325-333.

McDonagh, B., Tyther, R., and Sheehan, D. (2006). Marine Environmental Research, 62, S101-104.

Sheehan, D., and O’Donovan, E. (2006). Marine Environmental Research, 62, S411-S414.

Sluis-Cremer, N., and Dirr, H. (1995). FEBS Letters, 371, 94-98.

Yang,H.-L., Zeng,Q.-Y., Zhu,S.-G., and Zhou,X.-W. (2004). Comparative Biochemistry and Physiology B, 139, 175-182. 


\section{Figure captions}

Fig. 1. Labelling protein cysteines with iodoacetamide-fluorescein. A. Free thiols. B. Disulphide bridges. Spots (arrows) were identified by LC-tandem MS.

Fig. 2. Glutathione transferase forms disulphide bridges. A. Structural model of $M$. edulis GST P1-1. B. structure of mGSTP1-1 template. Conserved active site Tyrosines and cysteines are shown as sticks in white dashed boxes. For mGSTP1-1 (PDB code 1GLQ) the inhibitor S(p-nitrobenzyl) glutathione is presented in spacefill. C. Immunoblot with anti-mGSTP1-1 (left) and ponceau S stain (right) of: 1 and 2 Control gill; 3 and 4. Menadione-exposed gill. +/- denotes inclusion/omission of 2-mercaptoethanol in sample buffer. 


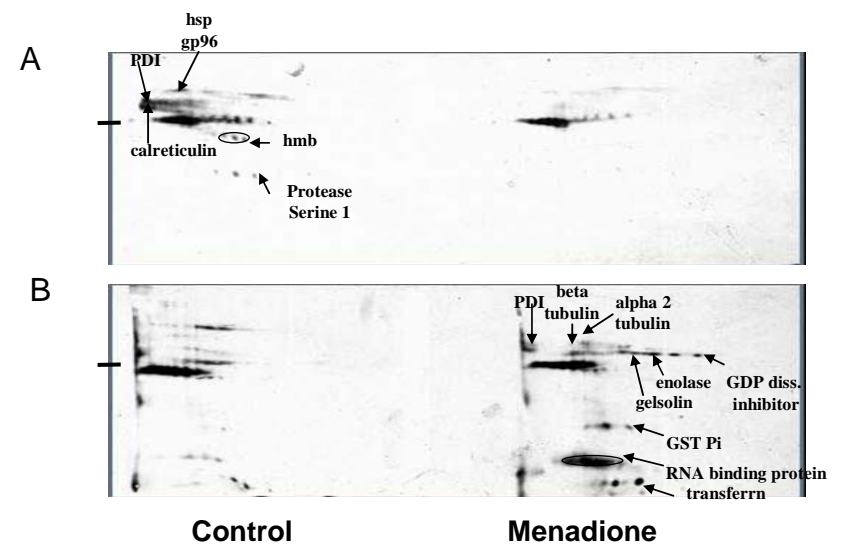

Fig. 1

A

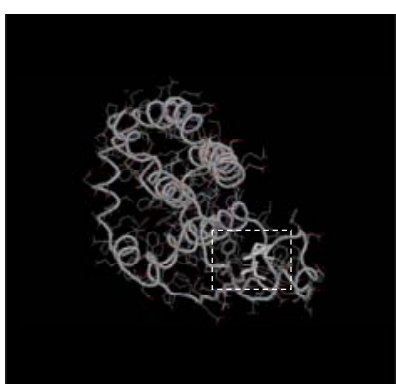

B

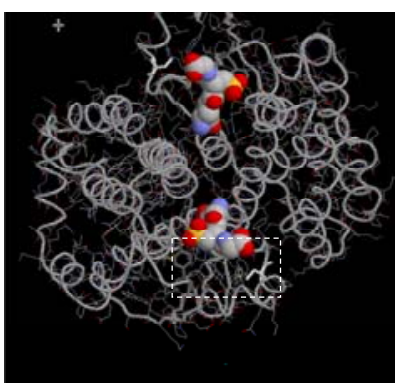

C

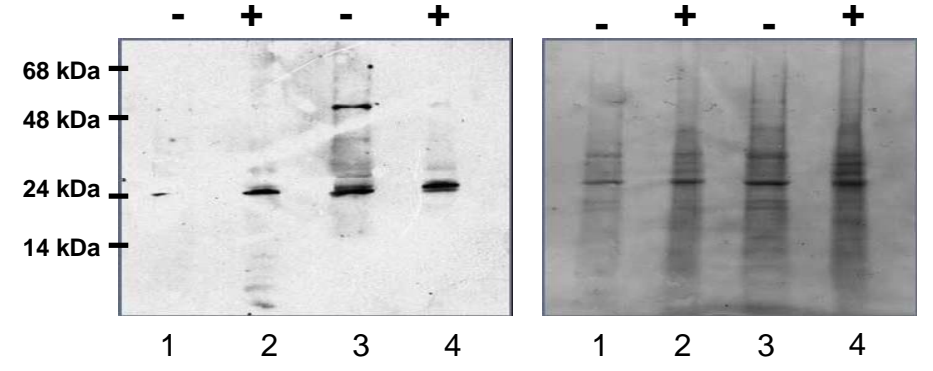

Fig. 2 